\title{
極微小地震の移動観測
}

\author{
京都大学理学部阿武山地震観測所 三木晴男 - 渡辺 晃 \\ 高知大学文理学部高知地震観測所 木 村 昌 三 \\ 京都大学理学部地球物理学教室 中村正夫 - 黒磯章夫 - 梅田康弘 \\ (昭和 41 年 12 月 14 日受理)
}

\section{Observations of Ultramicro-Earthquakes by Mobile System}

\author{
Haruo Miki and Hikaru Watanabe \\ Abuyama Seismological Observatory, Faculty of Science, Kyoto University; \\ Shozo KIMURA \\ Kochi Seismological Observatory, Faculty of Liberal Arts, Kochi University; \\ Masao Nakamura, Akio Kuroiso and Yasuhiro Umeda \\ Geophysical Institute, Faculty of Science, Kyoto University.
}

(Received Dec. 14, 1966)

Study of seismicity by means of mobile observations of ultramicro-earthquakes occupies an important position in the project of earthquake prediction in Japan. We searched the Matsushiro earthquake swarms for the problems and troubles involved in the study of seismicity by means of our mobile observation system.

In spite of the doubtful accuracy in determining the distribution of hypocenters from the frequency distribution of $S-P$ times, the results of our observations proved the reliability and the usefulness of the mobile observation system for the purpose of surveying the seismicity in a certain area and its variation with time. It proved to be especially useful in places where the seismicities could not be determined on a routine basis.

In order to get more precise information about the seismicity of ultramicro-earthquakes, the followings should be taken into consideration:

1) It is preferable that three component seismographs should be used in order to distinguish $P$ and $S$ as many earthquakes as possible, though it necessitates a heavy cargo.

2) It is necessary to devise some methods in order to account for the earthquakes which have indistinct $S-P$ times and are not accounted for consideration of the frequency distribution of $S-P$ times.

3) A cautious attitude should be taken in selecting places where the transducers are set up, in order to get seismic wave forms of good quality, though it reduces the area of observation.

4) Extensive studies on the physical processes which lie behind the time variations of seismic activities should be undertaken.

5) Long period observations which are much greater than the short period perturbations of seismicity should be carried out frequently. The intervals between each observation should be shorter than the periods of the variations of seismicity which being studied.

昭和 41 年 10 月 15 日地震学会で発表 


\section{目 的}

個々の地震の震源を求めて地震活動を調べることは，費用と人員（常時観測の場合）や組織 化（臨時の協同観測の場合）に伴ならいろいろな困難がある。そこで，一つ一つの地震の震源 を決めずに地震活動の地域性を推定する手段として，S-P の頻度分布から，全体としての震 源分布を求めたり (坪井 (1948); 浅田, 田 (1954)), 地震の起らない地域を求める (宮村 (1959)) ことなどが提案されている。これらの提案の考え方によると，極微小地震を観測することによ つて, 短期間に，したがつて機動的に，地震活動の状況を調査することができる筈である，地 震予知研究計画で機動観測班の設置が計画されているのもこういら意図に基づく.われわれ は，松代群発地震を移動観測することによつて，機動観測班の研究調査活動にともなう問題点 を実地に探つた。

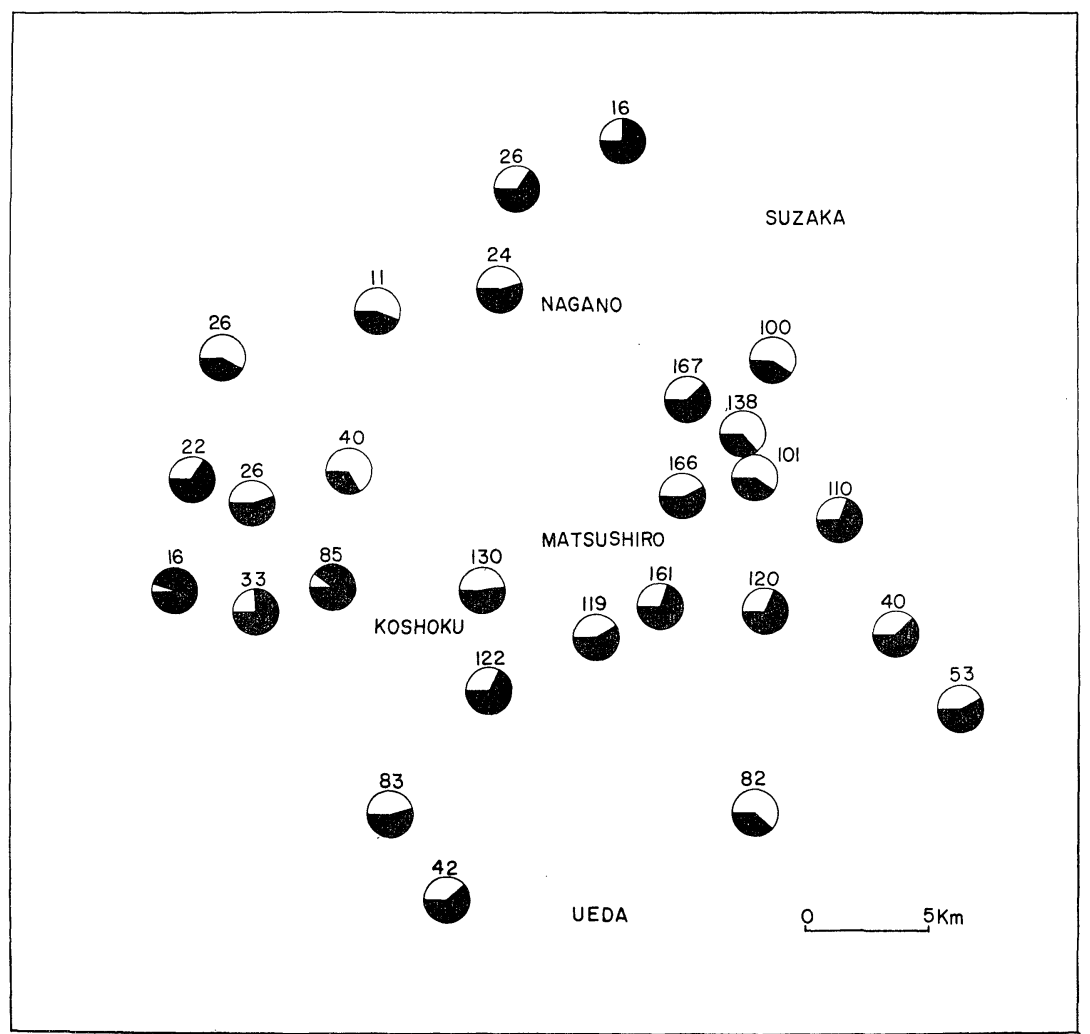

Fig. 1. Observation positions and numbers of earthquakes observed per 24 minutes by mobile observations with vertical component alone, in the neighbourhood of Matsushiro, in June 1966. Ratio of white and black portions of each circle correspond to the ratio of numbers of earthquakes whose $S-P$ times are readable and that of earthquakes whose $S-P$ times are not readable. 
装

備

第 1 回目の観測に用いた器械は，さきにわれわれが近畿地方全域にわたつて実施した雑微動 の移動観測の際に用いたものと同じで, $3 \mathrm{cps}$ 強力型換振器 (上下動一成分), 直流増幅器 (渡 辺測器) およびソニー可搬型データレコーダー (PPW 33 型) である。これ等をパブリカに積 載して, Fig. 1 の地点で, 昼間, 約 30 分間ずつ観測を行つた.

\section{観測結果とその検討}

Fig. 1 で, 数字は 24 分間に観測された地震の数を示し, 黒白で区分けされた円い図形は, 観測された地震のうち， $S-P$ が判読できた地震の数（白い部分）と判読できなかつた地震の 数 (黒い部分) の割合を示している.

$S-P$ の頻度分布をつくるといら立場から考えると，特に震源域から離れたところでは，観 測時間が短かすぎたようである。 $S-P$ が判読できた地震の数が比較的に少なかつた理由とし

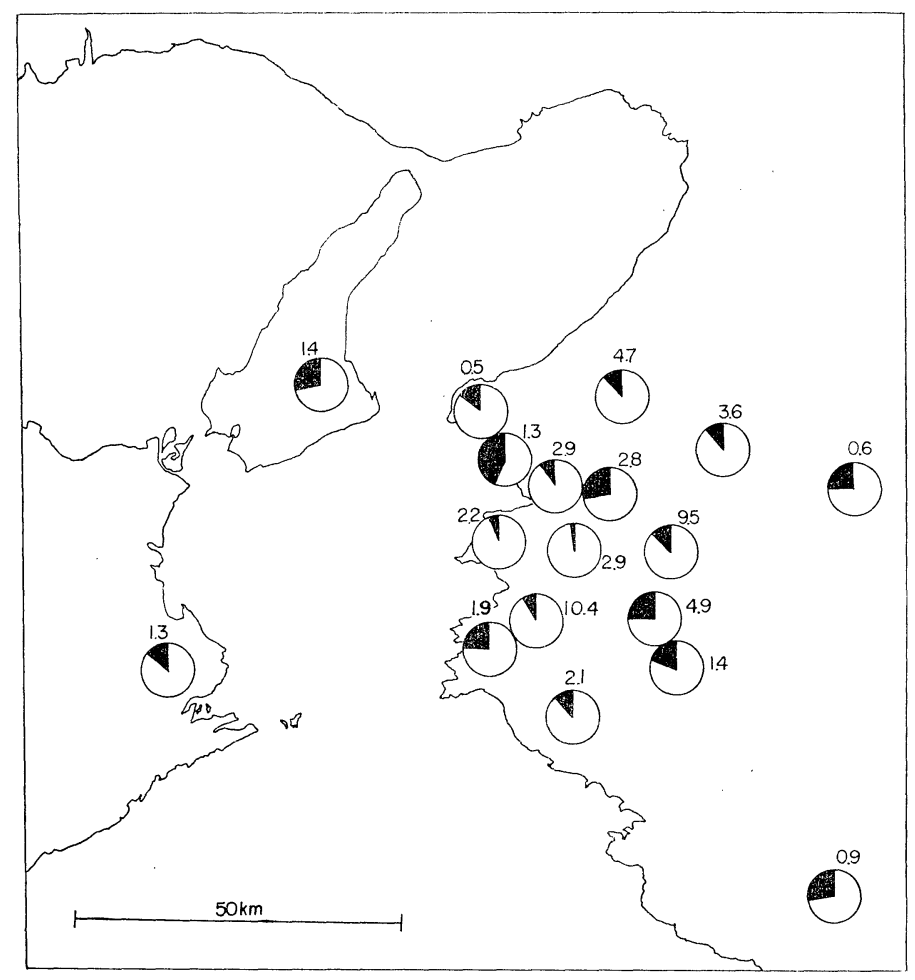

Fig. 2. Figure of the same kind as Fig. 1, except the numbers of earthquakes are indicated per one hour. Data were obtained from the results of the joint observations of ultramicro-earthquakes in the neighbourhood of Wakayama, in August 1965. 
ては

1. 荷物の積載をできるだけ少なくするために上下動 1 成分に限つたこと

2. 換振器設置場所が適当でなかつた

3. 観測時間が昼間であつたため雑微動に妨害された

ことなどが挙げられる。1965 年夏, 和歌山周辺で, 全国の大学による, 極微小地震の合同観 測が行なわれたが，その結果を，比較のために，Fig. 2 に示市. 図の中の数字は，Fig. 1 の 場合と違つて，1時間に観測された地震の数を示している，PとS の判読については, 非常 に成績が良い。

それにしても，S-P が判読できるのはすべての地震についてではない，すなわち，判読で きた $S-P$ か求めたその頻度分布が実際の震源分布を正しく反映しているといら保証はない。 もつとも，ぞういら方法で震源分布を決めるにせよ，これまでのところ，すべての地震につい て行なわれているのではなく，ある選び出された地震についての結果を，一般的なものとし て，拡大解釈しているのが現状であるから，移動観測についてだけすべての地震についての情 報を基礎にするよら要求するのは酷にすぎるかも知れない。しかし，選に漏れた地震が $S-P$ の頻度分布の形を変える可能性はあるのだから，その処遇について常に考慮を怠るべきではな い.

一例として，合同観測の際，下津木で観測した大阪工大班の報告をもとにして，S-P の頻 度分布をつくつてみると Fig. 3 のようになる。（この観測班の報告を引用したのは，この観 測班が忠実に多数の地震を報告しているという理由によるだけであつて，以下に述べる事情は 他の観測点でも同じである.）黒く塗りつぶした部分は他の観測点でも観測された地震，白い 部分は下津木のみで観測された地震を示している。この図から判断すると，1ケ所でしか観測 されなかつた地震が近距離でしか探知できない極微小地震とは限らないことが分る.

$S-P$ の頻度分布から地震活動を論じようとする考え方には上述のように根本的な難問が含 まれている。

ところで，松代での最初の観測の失敗を考慮して，水平動 1 成分を追加し（データレコーダ 一が 2 チャンネルだつたので，水平動 2 成分を追加することができなかつた，観測時間を延 長して，観測を継続した。第 2 回目以後の観測点はFig. 4 のとおりである。観測結果を北か ら順に Fig. 5 に示す. Fig. 5 の頻度分布で, 黒く塗りつぶした部分は上下動 1 成分のみで観 測しても S-P が判読できる地震の頻度を示している。この種の地震の数が多いか少ないか は, 地震群の発震機巧と観測点の相対的位置関係に依存するとともに, 換振器を設置した地点 の地盤の良否にも関係する。.Fig. 5 をみる限り，上下動 1 成分のみで観測しても $S-P$ の頻度 


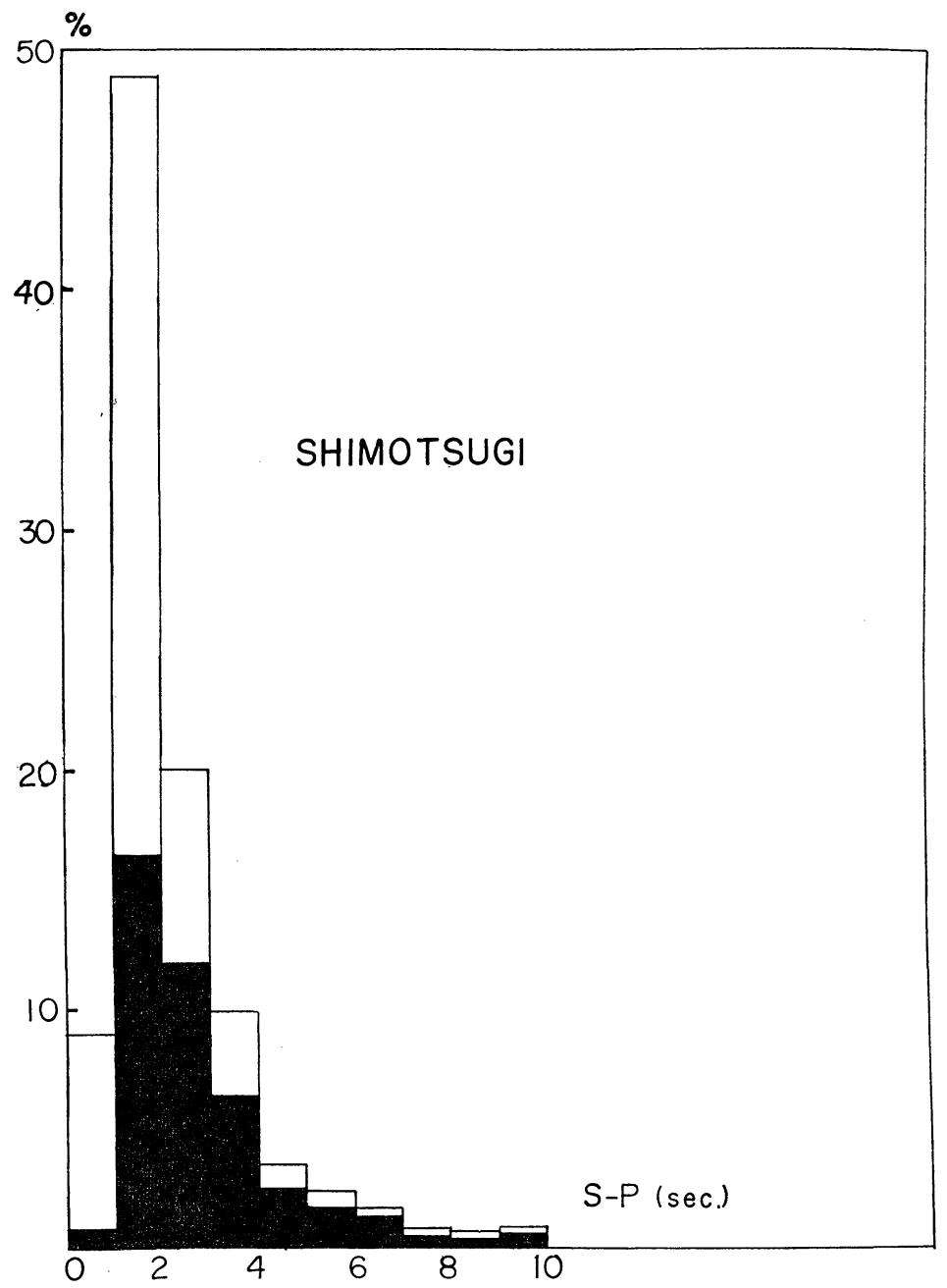

Fig. 3. Frequency distribution of $S-P$ times obtained from the data at Shimotsugi, Wakayama Pref., in August 1965. The black portions show the frequencies of earthquakes which were observed also at other stations. We can see in this figure that the earthquakes observed at one station alone (white portions) are not always considered as the ultramicro-earthquakes observable at very near stations, because the white portions exist even at great $S-P$ times (hypocentral distances). 


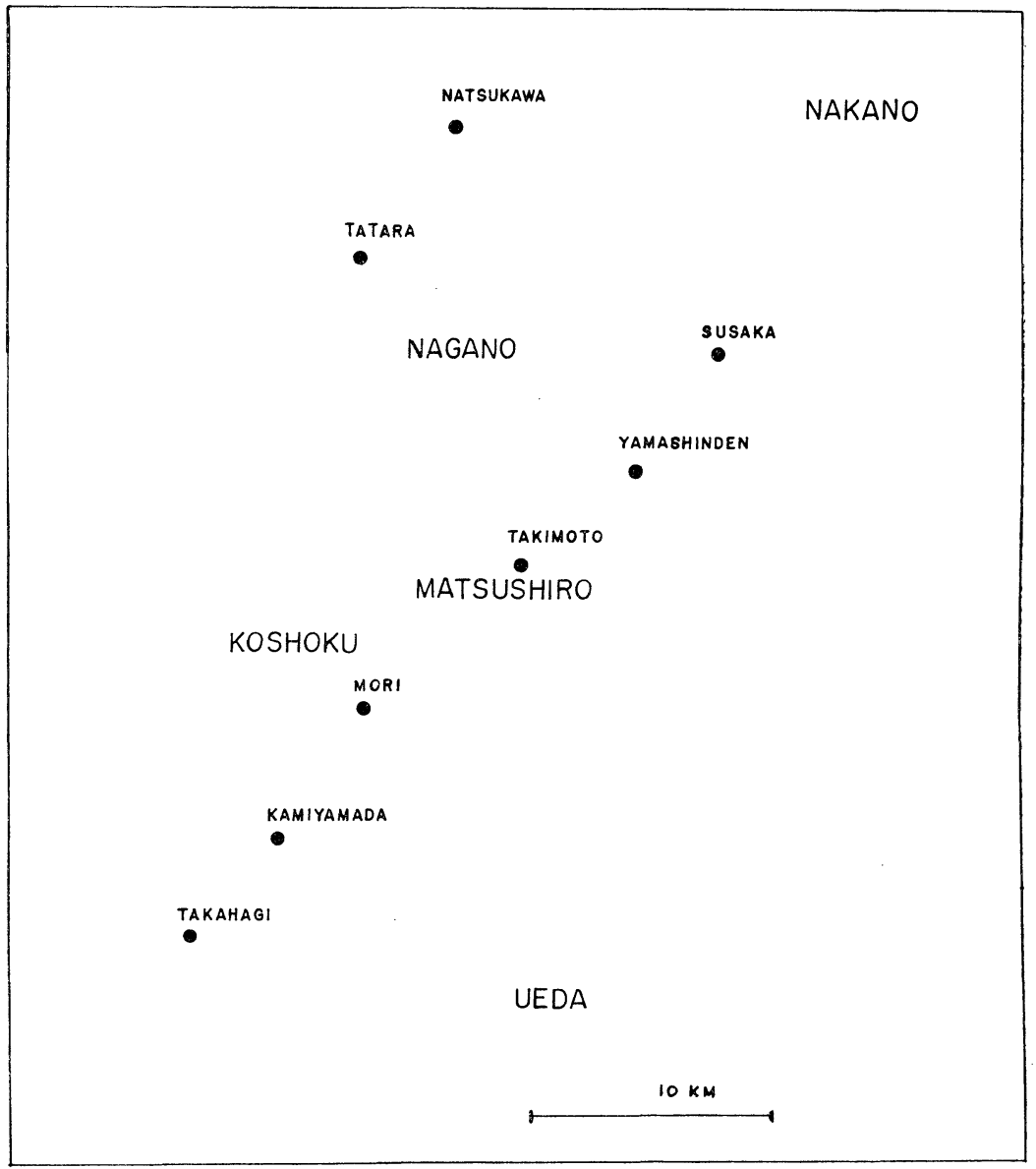

Fig. 4. Observation positions when improved mobile observations were carried out. The improvements were the addition of a horizontal component and the extension of the observation period.

分布の形はあまり変らないよらであるが，できるだけ多数の地震を採りあげるといら趣旨から は 3 成分観測が望ましい.Fig. 5 で, 黒白で区分けされた円い図形は, Fig. 1 の場合と同じ く, S-P が判読できた地震の数と判読できなかつた地震の数の割合を示している.

観測およびデータ処理に際して，気の付いたことは

1. 年礼村夏川と長野市釬の近辺には地震観測に適当な場所がない

2. 須坂市では $P$ が小さく

3. 更埴市森では $P$ が大きい

4. 更級郡上山田と坂井村高萩の $S-P$ 頻度分布は 7,8 月頃の震源域の移動と新たな発生 

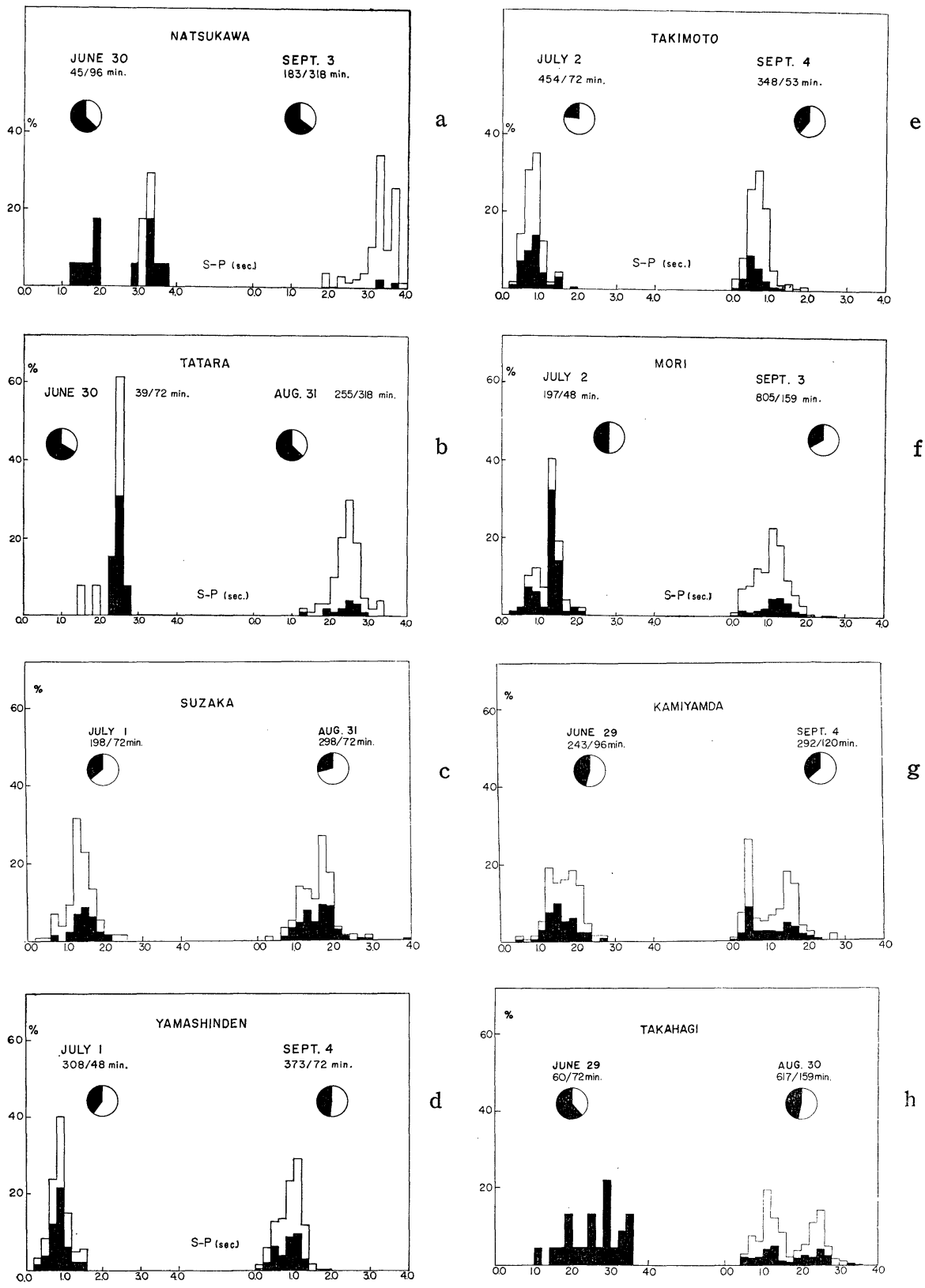

Fig. 5. Observation dates, numbers of earthquakes observed per observation period, and the frequency distributions of $S-P$ times, at temporary stations shown in Fig. 4. The meaning of the circles divided into black and white is the same as in Fig. 1. Columns with portions of black and white are drawn in order to test if the frequency distributions of $S-P$ times obtained from observations with a vertical transducer alone (black portions) and the ones obtained from the observations with vertical and horizontal transducers resemble each other or not. 
を明瞭に示している

ことなどである。

震源域の移動について連続的な情報を得るためには，連続観測を実施するに越したことはな いが，上述の結果をみると，簡便さといら点で, 移動観測にも捨てがたい魅力があることが分 る.

しかし，移動観測に伴ならもら一つの難点にも注意を払う必要がある．地震の連続観測をし ていて気がつくことに, 微小地震の場合でも, 地震は at random に起つているのではなく, 若干の群発性をもつているということがある，極微小地震の短時間の抜きとり観測はこの群発 性の影響をもろに受け，得られた結果が定常状態に対応しない可能性が大いにある.

いま，次のような平均値をつくつてみよう.

$$
P_{m}([S-P])=\frac{1}{n} \sum_{n=1}^{n} \frac{1}{m} \sum_{m=1}^{m} N_{m, n}
$$

この式の意味は次のと和りである。すべての地震の S-P は既知として, 観測された地震を, 発震時の順に, 並べる. $S-P$ の頻度分布をつくる場合と同様に, すべての地震の $S-P$ がどこ かの区間に入るように， $S-P$ を分類する。 上式の左辺は, ある $[S-P]$ 区間に属する地震の次 に発生した地震から数えて $m$ 個の地震をとつた場合, 同じ $[S-P]$ 区間に属する地震の発生 頻度を上述の地震系列について平均したものである。すなわち, 右辺の $m$ についての操作は 頻度を求めるためのもので， $n$ についての操作は平均を求めるためのものである. $N_{m, n}$ は, ある指定した $[S-P]$ 区間に属する地震の次の地震から数えて $m$ 個の地震のうち同じ $[S-P]$ 区 間に属する地震の数で， $n$ は地震系列の中で同じ $[S-P]$ 区間に属する地震群中の個々の地震 につけた通し番号である。

坂井村高萩で行つた観測結果から求めた計算結果を Fig. 6 に示す。この図は， $m$ が小さい とき，すなわち，ある着目した地震の発生後しばらくの間は，同じ $[S-P]$ 区間に属する地震 の発生確率が定常状態（mの大きい場合に対応する）での確率より大きいことを示している. したがつて，地震活動の時間的な消長の物理的な背景について研究を進めるとともに，移動観 測は目的とする地震活動の周期（時間的変化を便宜上こう名付けておく）より充分短い時間間 滆で，短周期の遙動を蔽うことができる程度の長時間観測を実施する必要がある.

\section{結語}

松代群発地震の移動観測を行つたが，移動観測による地震活動調査を行なら際に必要なるの として, 次の教訓を得た。 

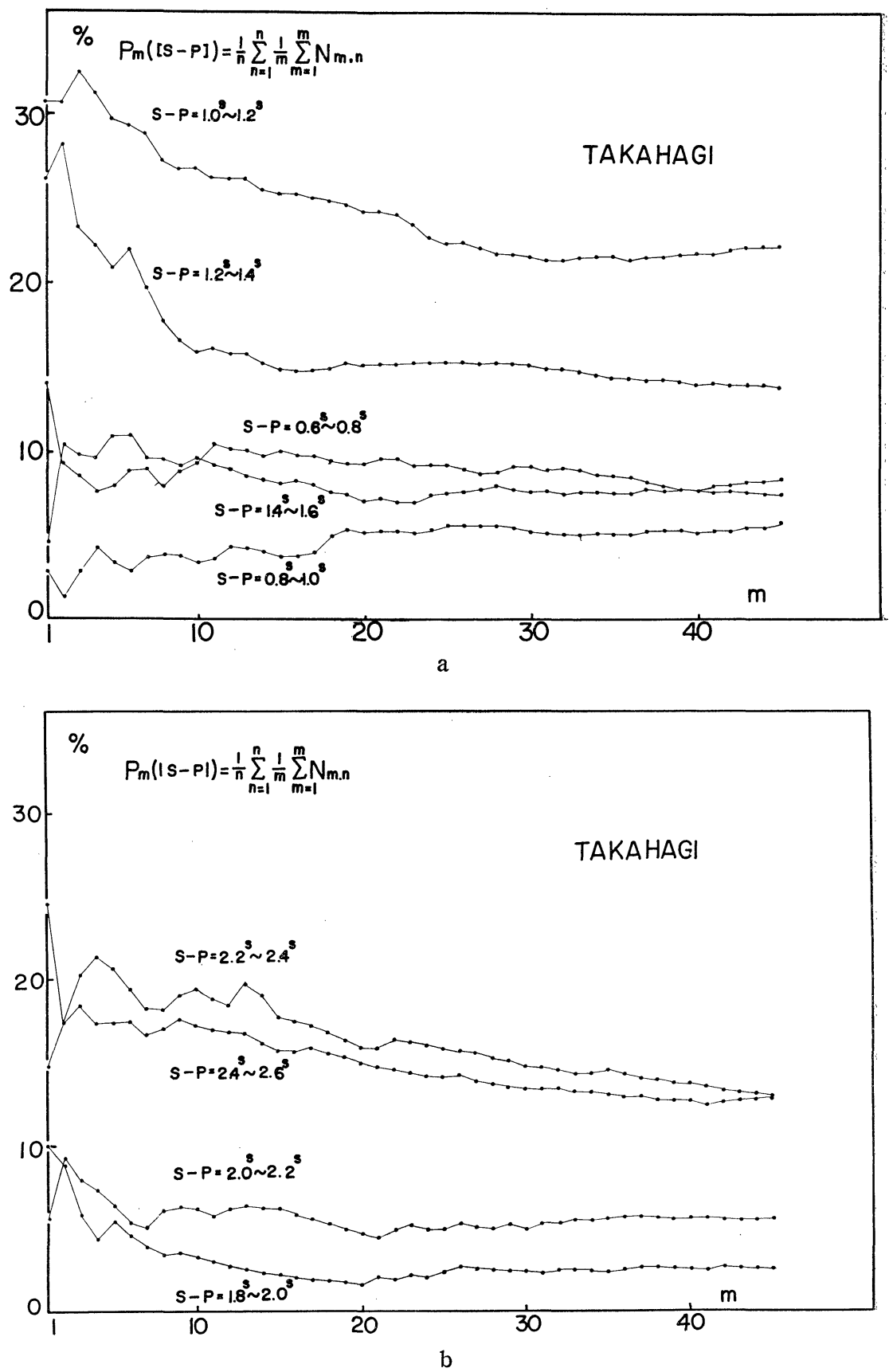

Fig. 6. Mean occurrence probabilities of an earthquake whose $S-P$ time falls into the assigned interval and occurs as the $m$ th earthquake after the one of the same assigned interval. 
1. 機材の積載が多くなるが，できるだけ多くの地震の $P$ と $S$ を判読するために，観測に は 3 成分地震計を用いることが望ましい。

2. $S-P$ が判読できなかつたため， $S-P$ 頻度分布に採りあげなかつた地震を, 地震活動調 査に積極的に用い得るような工夫が必要である.

3. 移動観測の活動範囲を狭めることになるが，良質の地震波形を得るために，換振器設置 場所を慎重に選定しなければならない.

4. 地震活動の時間的消長の物理的な背景について研究を進めるべきである.

5. 移動観測が目的とする地震活動が変化する周期より充分短い時間間隔で，地震活動の短 周期の摇動を蔽うことができる程度の長時間観測を実施する必要がある.

6. 上記の目的を達成するために，水準測量のベンチマークと同じく，必要な個所に地震計 台を恒久的に設けておくとよい。

\section{文献}

浅田 敏, 田 望 $1954, P-S$ 時間の頻度分布について, 地震 $2,7,37 \sim 44$.

宮村摂三 1959, 紀伊半島の局地地震 (第 3 報) 一一和歌山附近に括故る臨時地震観測網一一, 地震研 究所巢報, 37, 609 635.

虾井忠二 $1948, P S$ 時の頻度分布と震源の分布との関係, 地震 $2,1,8 \sim 11$. 